Research Article

\title{
Biogenic Silver Nanoparticles Synthesized Using Mexican Poppy Plant Inhibits Cell Growth in Cancer Cells through Activation of Intrinsic Apoptosis Pathway
}

\author{
Kailas Dhondibhau Datkhile , Satish Ramchandra Patil, Pratik Prakash Durgawale, \\ Madhavi Narayan Patil, Nilam Jagannath Jagdale, Vinit Nitin Deshmukh, Ashwini Laxman More \\ Department of Molecular Biology and Genetics, Krishna Institute of Medical Sciences, Taluka-Karad, Dist-Satara, Pin-415 539, \\ Maharashtra, India.
}

—Corresponding authors. E-mail: hodgeneticslab@kimsuniversity.in Tel.: 02164-241555/56/57/58 Extn-469 Fax: 02164-243273

Received: Mar. 14, 2020; Accepted: Jul. 22, 2020; Published: Aug. 28, 2020

Citation: Kailas Dhondibhau Datkhile, Satish Ramchandra Patil, Pratik Prakash Durgawale, Madhavi Narayan Patil, Nilam Jagannath Jagdale, Vinit Nitin Deshmukh, and Ashwini Laxman More, Biogenic Silver Nanoparticles Synthesized Using Mexican Poppy Plant Inhibits Cell Growth in Cancer Cells through Activation of Intrinsic Apoptosis Pathway. Nano Biomed. Eng., 2020, I2(3): 24I-252.

DOI: 10.5101/nbe.v12i3.p241-252.

\begin{abstract}
In the present investigation, biogenic silver nanoparticles were synthesized using aqueous extract of Mexican poppy plant Argemone mexicana (AM-Ag NPs); their involvement in striking cytotoxicity and genotoxicity potential was explored. The biosynthesis of nanoparticles was confirmed by ultraviolet-visible spectroscopy (UV-Vis) and characterized by scanning electron microscopy (SEM), transmission electron microscopy (TEM), Fourier transform-infrared spectrometry (FTIR) and X-ray diffraction (XRD). The mechanism of inhibition of cell proliferation by Ag NPs was illustrated using human cervical adenocarcinoma (HeLa), human breast adenocarcinoma (MCF-7) and human colon adenocarcinoma (HCT-15) cells. In selected cancer cells, molecular mechanism involved in induction of apoptosis in response to biogenic Ag NPs was demonstrated by DNA fragmentation assay, and alteration in expression of apoptotic genes including caspase-3 and p53 was analyzed by RT-PCR and western blotting. The overall results construed that biosynthesized AM-Ag NPs exhibited cytotoxicity effect against tested HeLa, MCF-7 and HCT-15 cell lines in a dose dependent manner where $20 \mu \mathrm{g} /$ $\mathrm{mL}$ concentration of AM-Ag NPs killed more than 95\% of HeLa and MCF-7 cells after $24 \mathrm{~h}$ exposure, whereas HCT-15 cells required $50 \mu \mathrm{g} / \mathrm{mL}$ AM-Ag NPs to inhibit 95\% cell growth. AM-Ag NPs significantly induced cellular DNA damage in HeLa and MCF-7 cells when treated up to $20 \mu \mathrm{g} / \mathrm{mL}$ and HCT-15 cells exposed up to $50 \mu \mathrm{g} / \mathrm{mL}$ concentrations for $24 \mathrm{~h}$. It is evident from our finding that the underlying mechanism of cell death in cancer cells exposed to AM-Ag NPs was intrinsic apoptosis pathway mediated by activation of caspase- 3 and p53 genes.
\end{abstract}

Keywords: Argemone mexicana; AM-Ag NPs; Cytotoxicity; Genotoxicity; Apoptosis

\section{Introduction}

Over the recent years, numerous studies have been carried out on biological synthesis of metal nanopartticles and their utilization in industrial and agriculture applications which are now building enormous interest in the healthcare sector too [1].
Amongst them silver and gold nanoparticles are widely studied for their synthesis using plant extracts and their comprehensive applications. Phytochemicals from different parts of plants such as leaves, stem, roots, shoots, flowers, bark and fruits have been utilized for synthesis of nanoparticles especially silver and gold nanoparticles [2-5]. Several reviews have been made 
available of the synthesis and characterization of silver nanoparticles but with limited information on their mechanism of action $[6,7]$. Nowadays, biosynthesized nanoparticles have emerged as novel therapeutic approach in healthcare system for the mechanistic management of both infectious as well as noninfectious diseases. Particularly, silver nanoparticles are widely noted for their antimicrobial properties against broad range of bacterial species [7, 8] and anticancer properties [9-13]. The cytotoxicity of silver nanoparticles is reported to be triggered by oxidative stress induced by free radicals such as reactive oxygen species (ROS) which inhibits cell proliferation through induction of programmed cell death [14-16]. But the clear molecular mechanism involved in arrest of cell proliferation remains unresolved dispute till date.

Currently employed chemotherapeutic approach dealing with cancer cells but facing severe obstacles such as multi drug resistance and severe aftereffects are considered as notable downsides in cancer management which results cancer as influential executioner all around the world. Subsequently, the discovery of new cancer targeting strategy with progressively influential and low harm to host immune system has become a basic objective in chemotherapeutics. Therefore, there is a developing interest in growing new and increasingly compelling classes of adjuvant therapeutic remedy for advanced cancer management with better biocompatibility and effectiveness. Use of biogenic nanoparticles is one of the rising and most promising therapeutic contrivances extensively studied in past few decades for their effectiveness against cancer cells. It has been reported earlier that silver nanoparticles can induce cell death through oxidative stress and p53 mediated apoptotic pathway in human carcinomas $[17,18]$. Also, very recently, Bethu et al. proposed the anticancer activity of silver nanoparticles synthesized using Rhynchosia suaveolens was because of trigger in apoptosis signaling pathway in human ovarian, prostate and lung cancer cell lines [19]. Similarly, Kanipandian et al. reported induction of intrinsic apoptosis pathway in lung cancer cell lines in response to silver nanoparticles synthesized using Gossypium hirsutum [20].

In order to substantiate these findings, this study was intended to synthesize silver nanoparticles biogenically using fresh leaf extracts of Argemone mexicana L. and to explore possible mechanism involved in inhibition cell proliferation. Argemone mexicana is commonly known as Mexican poppy plant reported with multiple medicinal benefits [21, 22]. Earlier bio-synthesized silver nanoparticles using A. mexicana were studied for their antimicrobial and antioxidant potential [23, 24]. However, possible mechanism involved in cytotoxicity and genotoxicity effects of either of silver or any other type of metal nanoparticles synthesized using A. mexicana plant extract remain unrevealed. Therefore, in the present study, we have attempted to evidence the molecular events involved in cytotoxicity and genotoxicity of Argemone mexicana silver nanoparticles (AM-Ag NPs) against various cancer cell lines including HeLa, MCF-7 and HCT-15. The cytotoxicity potential of AM-Ag NPs was explored by 3-(4,5-dimethylthiazol-2yl) 2-5-diphenyltrazolium bromide (MTT) colorimetric assay. The possible molecular mechanism of action for cell death or apoptotic features was addressed through DNA fragmentation assay; alterations in apoptotic genes at mRNA and protein level were determined by semiquantitative reverse transcriptase-polymerase chain reaction (RT-PCR) and western blotting, respectively.

\section{Experimental Materials}

HeLa, MCF-7 and HCT-15 cells were procured from National Centre for Cell Sciences, Pune. Minimum essential medium (MEM), RPMI1640, fetal bovine serum (FBS), trypsin-EDTA, and penicillin-streptomycin were purchased from Gibco. 3-(4,5-dimethylthiazol-2-yl)-2,5-diphenyltetrazolium bromide (MTT) was from Sigma. $\mathrm{AgNO}_{3}$, Tris-HCl, ethylenediaminetetraacetate, Triton X-100, PMSF, dithiothreitol, and sodium dodecyl sulphate were from Sisco Research Laboratories. Caspase-3, p-53, and anti-actin, goat anti-rabbit IgG and rabbit antimouse IgG antibodies were from Abcam. Other equipment included WesternBright ${ }^{\mathrm{Tm}}$ ECL detection system (Advansta), Verso cDNA synthesis kit (Thermo Scientific), Taq DNA polymerase, dNTPs, and low EEO agarose from (GeNei)

\section{Biosynthesis and purification of silver nanoparticles}

The silver nanoparticles were synthesized by adding $10 \mathrm{~mL}$ of aqueous plant extract of A. mexicana to $90 \mathrm{~mL}$ of 1 mili molar $(\mathrm{mM})$ silver nitrate $\left(\mathrm{AgNO}_{3}\right)$ solution. The preparation was then incubated at 80 ${ }^{\circ} \mathrm{C}$ in dark with continuous shaking and monitored for synthesis of nanoparticles with change in colour of reaction mixture. After formation of AM-Ag NPs, 
the mixture was centrifuged at $15,000 \mathrm{rpm}$ for 10 min and washed several times with sterile deionized distilled water (ddw) to remove unwanted traces of contaminants followed by redispersion of the pellet in sterile ddw for further characterizations.

\section{Visual observation}

The reduction of silver nitrate using aqueous plant extract was monitored for time periods of $0.5,1,2$, 3, 4 and $5 \mathrm{~h}$, and the appearance of dark brown color indicated the formation of silver nanoparticles.

\section{UV-visible spectroscopy analysis}

Preliminary characterization of biosynthesized Ag NPs was carried out using UV-visible spectroscopy. The bio-reduction of pure silver ions was monitored by scanning ultraviolet-visible spectra of the reaction mixture at a wavelength of $300-800 \mathrm{~nm}$ by sampling the aliquots withdrawn from reaction mixture at different time intervals. The measurements were recorded on UV-visible dual beam spectrophotometer, UV-1800 Shimadzu.

\section{Characterization of biogenic AM-Ag NPs}

Characterization of biosynthesized AM-Ag NPs was carried out by SEM, TEM, XRD and FTIR at Sophisticated Analytical Instrument Facility at Sophisticated Test and Instrumentation Centre, Cochin University, Kerala.

\section{In vitro evaluation of cytotoxicity activity of AM-Ag NPs \\ Cell lines and cell culture}

The HeLa and MCF-7 cells were maintained in T-25 flasks containing MEM media, whereas HCT-15 cells were maintained in RPMI1640 media along with $10 \%$ heat inactivated FBS and penicillin-streptomycin at $100 \mathrm{U} / \mathrm{mL}$ and $100 \mu \mathrm{g} / \mathrm{mL}$ respectively. Cells were maintained under an atmosphere of $5 \% \mathrm{CO}_{2}$, $95 \%$ humidity and $37{ }^{\circ} \mathrm{C}$ temperature. The primary fibroblasts cells obtained from breast tissue were cultured in DMEM/F12 media supplemented with containing FBS (10\%), Pen-strep100 (U/mL), EGF (10 $\mathrm{ng} / \mathrm{mL})$, insulin $(5 \mu \mathrm{g} / \mathrm{mL})$, pituitary extract $(50 \mathrm{ng} / \mathrm{mL})$, and hydrocortisone $(0.5 \mu \mathrm{g} / \mathrm{mL})$.

\section{In vitro cell viability assay}

To study the inhibitory effects of AM-Ag NPs, the cells were maintained in MEM, RPMI-1640 as well as DMEM/F12 medium supplemented with $10 \%$ FBS, penicillin-streptomycin at $100 \mathrm{U} / \mathrm{mL} / 100 \mu \mathrm{g} / \mathrm{mL}$ in a humidified atmosphere of $5 \% \mathrm{CO}_{2}$ at $37^{\circ} \mathrm{C}$. 10,000 cells in $200 \mu \mathrm{L}$ of respective medium per well were seeded in a 96 well plate and incubated at $37^{\circ} \mathrm{C}$, $5 \% \mathrm{CO}_{2}$. After $24 \mathrm{~h}$ incubation, confluent cells were exposed to different concentrations of $0.5,1.0,2.5,5$, $7.5,10,15,20,25$ and $50 \mu \mathrm{g} / \mathrm{mL}$ of nanoparticles in culture medium without FBS and incubated for further $48 \mathrm{~h}$ at $37^{\circ} \mathrm{C}, 5 \% \mathrm{CO}_{2}$. Thereafter, $10 \mu \mathrm{L} /$ well of 5 $\mathrm{mg} / \mathrm{mL}$ concentration of MTT was added to the cells and further incubated for another $4 \mathrm{~h}$ at $37^{\circ} \mathrm{C}$. After $4 \mathrm{~h}$ incubation, $200 \mu \mathrm{L}$ of DMSO was added to each well to dissolve the formazan crystals. The absorbance of purple color developed was measured at $560 \mathrm{~nm}$ wavelength using UV-Visible 1800 Spectrophotometer to determine percentage inhibition of growth of treated as well as untreated cells.

\section{DNA fragmentation assay}

In order to check apoptosis, DNA fragmentation assay was performed. In brief, $1 \times 10^{6}$ cells $(\mathrm{HeLa}$ and MCF-7) in 6 well plates were treated with 2.5, 5, 10, 15 and $20 \mu \mathrm{g} / \mathrm{mL}$, and HCT-15 cells treated with 5, 10, 20, 25 and $50 \mu \mathrm{g} / \mathrm{mL}$ concentrations of AM-Ag NPs along with untreated controls and incubated at 37 ${ }^{\circ} \mathrm{C}$ in $5 \% \mathrm{CO}_{2}$ for $24 \mathrm{~h}$. Cells were lysed in $0.3 \mathrm{~mL}$ of cell lysis buffer containing $10 \mathrm{mM}$ Tris-HCl, $\mathrm{pH}$ 7.5, 1 mM EDTA, $0.2 \%$ Triton X-100, and 0.5\% SDS. The cell lysate was incubated with $0.5 \mathrm{mg} / \mathrm{mL}$ RNase A at $37^{\circ} \mathrm{C}$ for $1 \mathrm{~h}$. DNA in aqueous phase was precipitated by adding $1 / 10^{\text {th }}$ volume of $5 \mathrm{M}$ sodium chloride and equal volume of isopropanol at room temperature. After $1 \mathrm{~h}$ incubation, the suspension was centrifuged at $12,000 \mathrm{rpm}$ for $30 \mathrm{~min}$ at $4{ }^{\circ} \mathrm{C}$ followed by DNA pellet wash by $70 \%$ ice cold ethanol and air-dried DNA pellet for $10 \mathrm{~min}$ at room temperature. The DNA was re-suspended in appropriate volume of $\mathrm{T}_{10} \mathrm{E}_{1}$ buffer (pH 8.0). DNA was checked on $1.5 \%$ (w/v) low EEO agarose gel containing $1 \mu \mathrm{g} / \mathrm{mL}$ ethidium bromide. The DNA fragments were visualized by exposing the gels to UV transilluminator followed by photography in gel documentation system (BioRad Laboratories, USA).

\section{Semiquantitative RT-PCR analysis for apoptotic gene expression}

The change in expression profile of caspase- 3 and p53 genes was identified using RT-PCR analysis. In this study, total RNA was extracted from control and AM-Ag NP ( $\mathrm{IC}_{50}$ concentration) treated cells by the Trizol reagent. The cDNA was synthesized from equal amounts of RNA (5 $\mu \mathrm{g})$ using cDNA synthesis kit in $20 \mu \mathrm{L}$ reaction containing $1 \mu \mathrm{L}$ verso enzyme 
mix containing reverse transcriptase, $4 \mu \mathrm{L} 5 \times$ cDNA synthesis buffer, $2 \mu \mathrm{L}$ of dNTPs ( $0.5 \mathrm{mM}$ each), $1 \mu \mathrm{L}$ of RT enhancer, $1 \mu \mathrm{L}$ of mixture of random hexamers and anchored oligo dT (3:1). cDNA synthesis was performed by reverse transcription cycling programme at $42{ }^{\circ} \mathrm{C}$ for $30 \mathrm{~min}$ followed by inactivation at $95{ }^{\circ} \mathrm{C}$ for 2 min to remove contaminating DNA. Thereafter, semi-quantitative RT-PCR amplification was performed where $2 \mu \mathrm{L}$ of each cDNA was amplified in a $20 \mu \mathrm{L}$ PCR reaction mixture containing 1 unit Taq DNA polymerase, $2 \mu \mathrm{L} 10 \times$ PCR buffer, $0.5 \mu \mathrm{L}$ of dNTP (200 $\mu \mathrm{M}$ each) and 10 picomoles of respective primers (caspase-3 forward primer 5'-gtggcattgagacagacagtgg-3' caspase-3 reverse primer 5'-gccaagaataataaccaggtgc-3' and p53 forward primer 5'-actaagcgagcactgcccaa-3' reverse primer 5'-atggcgggaggtagactgac-3'). The cycling conditions were comprised of an initial denaturation of $5 \mathrm{~min}$ at $94{ }^{\circ} \mathrm{C}$ followed by 30 cycles of amplification at $94{ }^{\circ} \mathrm{C}$ for $30 \mathrm{sec}, 50{ }^{\circ} \mathrm{C}$ for $30 \mathrm{sec}$ and $72{ }^{\circ} \mathrm{C}$ for 30 sec, and the final elongation step at $72{ }^{\circ} \mathrm{C}$ for $10 \mathrm{~min}$. To control the $\mathrm{PCR}$ reaction components and the integrity of the RNA, $2 \mu \mathrm{L}$ of each cDNA sample was amplified separately for b-actin specific primers (forward primer 5'-tctggcaccacaccttctacaatg-3' reverse primer 5'-agcacagcctggatagcaacg-3'). Electrophoretic separation of amplification products was performed with $2.5 \%$ agarose gel in TBE buffer. Relative density of ethidium bromide stained amplicons was determined using image analysis software Image Lab 3.0 software (BioRad, USA)

\section{Western blotting analysis}

Western blotting was performed to detect the expression of apoptotic proteins such as caspase-3 and p53 in HeLa, MCF-7 and HCT-15 cells. $1 \times 10^{6}$ cells grown in 6 well plates and treated with $\mathrm{IC}_{50}$ concentration of AM-Ag NPs for $48 \mathrm{~h}$, and were harvested with centrifugation at 12,000 rpm for 10 min at $24 \mathrm{~h}$ intervals. Cell pellet was immediately lysed in homogenizing buffer (50 mM Tris, $5 \mathrm{mM}$ EDTA, 0.1\% Triton X-100, 1 mM PMSF, 0.5 mM DTT, and protease inhibitor cocktail); cell lysates were centrifuged at $12,000 \mathrm{rpm}$ at $4{ }^{\circ} \mathrm{C}$. Defined amount of total protein (50 $\mathrm{\mu g} /$ lane) was separated on $10 \%$ SDS-PAGE and then transferred onto a nitrocellulose membrane. Subsequently, membranes were blocked in TBST solution containing $5 \%$ casein for $1 \mathrm{~h}$ followed by probing with primary antibodies, rabbit anti-caspase-3, anti-actin and mouse anti-p53. After washing with TBST solution, the membranes were incubated with secondary antibodies (horseradish peroxidase-conjugated goat anti-rabbit IgG and rabbit anti-mouse IgG). Immunoreactive bands were detected using enhanced chemiluminescence WesternBright ${ }^{\mathrm{Tm}}$ ECL detection system.

\section{Statistical analysis}

All statistical analyses were performed with SPSS for windows version 11.0 software. The $\mathrm{IC}_{50}$ values with $95 \%$ confidence interval (50\% cell growth inhibitory concentration) were reported as Mean \pm SEM of 3 independent experiments. Student's t-test was performed to examine the significant differences between means of AM-Ag NPs treated and control samples.

\section{Results and Discussion}

This study helped to understand possible mechanism underlying the cytotoxicity and genotoxicity of biogenic silver nanoparticles synthesized using A. mexicana plant extract. This is the first report of its kind to provide evidence supporting AM-Ag NPs exhibited significant anti-proliferative and apoptotic potential against selected cancer cells, which suggeseds that biogenic AM-Ag NPs could be a new subsidiary therapeutic means for the treatment of variety of cancers.

\section{Biosynthesis and characterization of $\mathrm{AM}-\mathrm{Ag}$ NPs}

Biosynthesis of AM-Ag NPs using aqueous leaf extract of A. mexicana was demonstrated by change in colour of silver nitrate from colorless to brownish within 5 h of incubation at $80{ }^{\circ} \mathrm{C}$ (Fig. 1(a) and (c)). The change in color of $\mathrm{AgNO}_{3}$ solution after incubation with A. mexicana leaf extract confirmed the formation of different sized silver nanoparticles which was triggered by secondary metabolites in phytochemicals present in A. mexicana responsible for bioreduction of silver ions to nanosilver. Further confirmation and characterization of biosynthesized AM-Ag NPs were done by UV-visible spectroscopy where the colloidal solution of AM-Ag NPs showed absorption peak at $440 \mathrm{~nm}$ (Fig. 1(b)). Furthermore, time dependent bioreduction of silver ions into AMAg NPs in colloidal solution was monitored at various time intervals of $30 \mathrm{~min}, 1 \mathrm{~h}, 2 \mathrm{~h}, 3 \mathrm{~h}, 4 \mathrm{~h}$ and $5 \mathrm{~h}$ respectively. The formation of AM-Ag NPs was started after $1 \mathrm{~h}$ of incubation and completed after $5 \mathrm{~h}$ (Fig. 1(d)). 

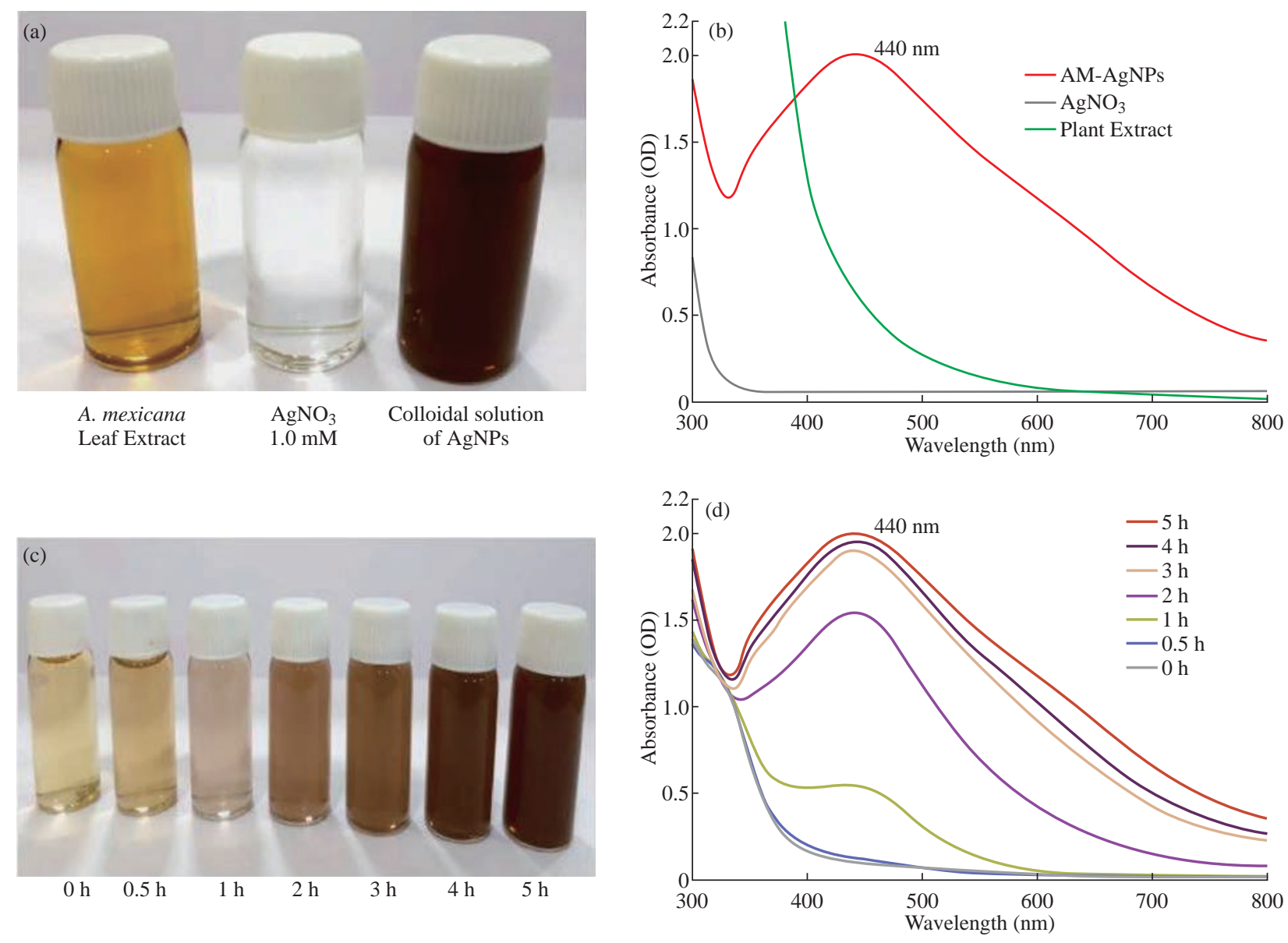

Fig. 1 Biosynthesis of AM-Ag NPs, bottle containing (a) A. mexicana plant extract, sample of $1 \mathrm{mM} \mathrm{AgNO}_{3}$ and colloidal solution of AM-Ag NPs. (b) UV-visible spectra of A. mexicana plant extract, $\mathrm{AgNO}_{3}$ and $\mathrm{AM}-\mathrm{Ag}$ NPs. The absorption spectrum exhibited a strong broad peak between 432 - $442 \mathrm{~nm}$ for Ag NPs. (c) Time dependent synthesis of biogenic AM-Ag NPs. Transformation of color of reaction mixture containing A. mexicana leaf extract and silver nitrate solution at various time periods $(0-5 \mathrm{~h})$. Time dependent UV-visible spectrometry analysis of formation of AM-Ag NPs at various time periods. The absorption spectrum exhibited a strong broad peak between $440 \mathrm{~nm}$ for Ag NPs.

The results of SEM revealed distribution of AMAg NPs (Fig. 2(a)). The morphology, size and shape of biosynthesized AM-Ag NPs were determined by TEM which showed the biosynthesized AM-Ag NPs were spherical in shape and $20-60 \mathrm{~nm}$ in size range (Fig. 2(b)). When we determined the size of AM-Ag NPs by dynamic light scattering (DLS), the results showed average size of AM-Ag NPs at $48.8 \mathrm{~nm}$. (Supporting Information 1). XRD was used to confirm the crystalline nature of biosynthesized AM-Ag NPs where the pattern of important peaks at $2 \theta$ values of $37.99^{\circ}$, $44.15^{\circ}, 64.40^{\circ}$ and $77.36^{\circ}$ corresponding to 111,200 , 220 and 311 planes of silver confirmed the crystalline nature of biogenic AM-Ag NPs (Fig. 2(c)). The FTIR peaks at 3449, 2019, 1631, 1383 and 566 confirmed $\mathrm{O}-\mathrm{H}, \mathrm{C}-\mathrm{H}$ and $\mathrm{C}-\mathrm{N}$ stretching of polyphenolic compounds during the formation of biogenic Ag NPs. Thus, the results of FTIR confirmed the role of phytochemicals present in A. mexicana in the process of biogenic synthesis and stabilization of nanoparticles (Fig. 2(d)).

\section{Cytotoxicity of AM-Ag NPs}

A number of studies revealed possible restorative prospective of biogenic silver nanoparticles on human cancer cell lines including human breast cancer cell line [20,25] and lung cancer cell lines [26]. However, very limited information appeared in literature elucidating the mechanism involved in action of nanoparticles on cellular pathways during the inhibition of cell proliferation process. Therefore, in this study we demonstrated the evident mechanism of action of AM-Ag NPs on activation of apoptotic pathway in cancer cells. In the present study we found that AM-Ag NPs exerted growth inhibitory effects on studied breast and cervical cancer cell lines at concentration dependent manner where minimum concentration $(20 \mu \mathrm{g} / \mathrm{mL})$ inhibited more than $90 \%$ 


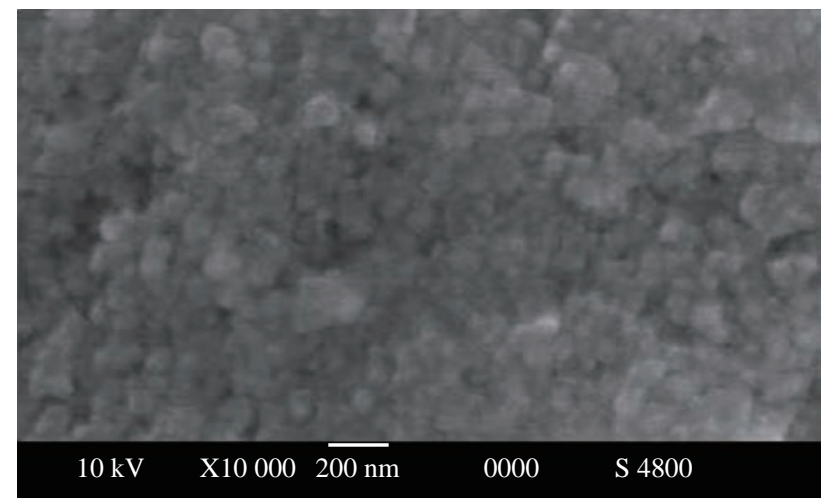

(a) Scanning electron micrograph of AM-AgNPs

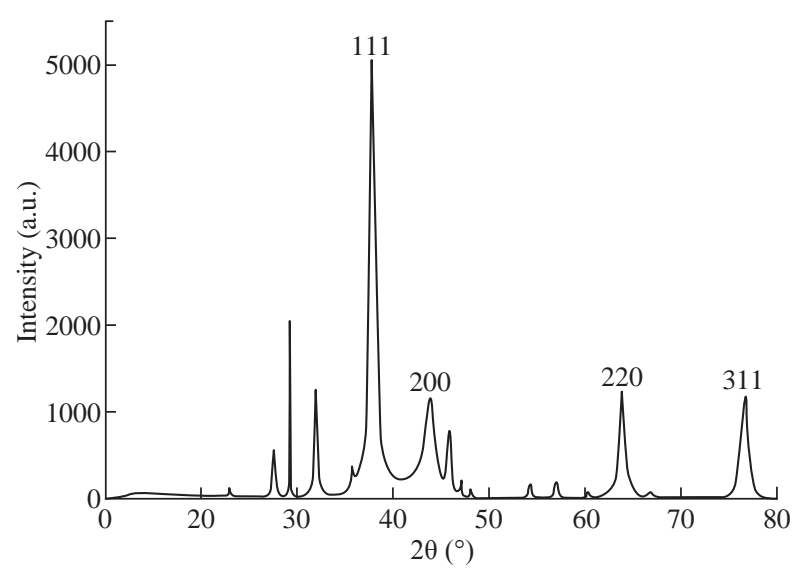

(c) X-ray diffraction spectrum of AM-AgNPs

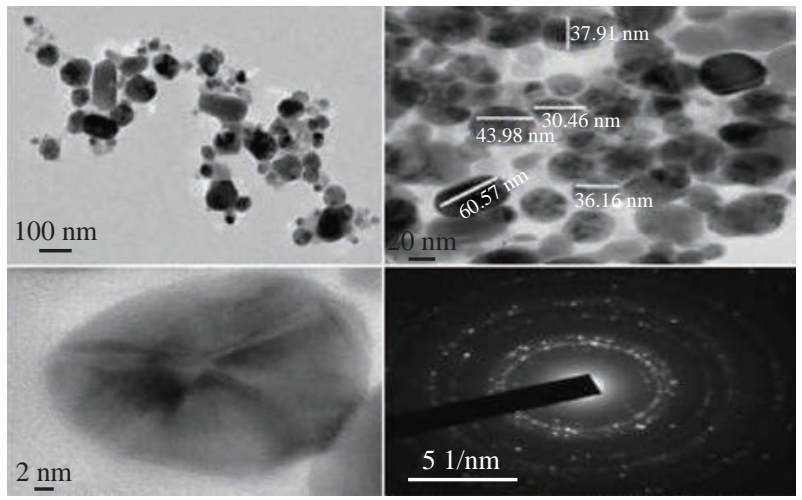

(b) Transmission electron micrograph of AM-AgNPs

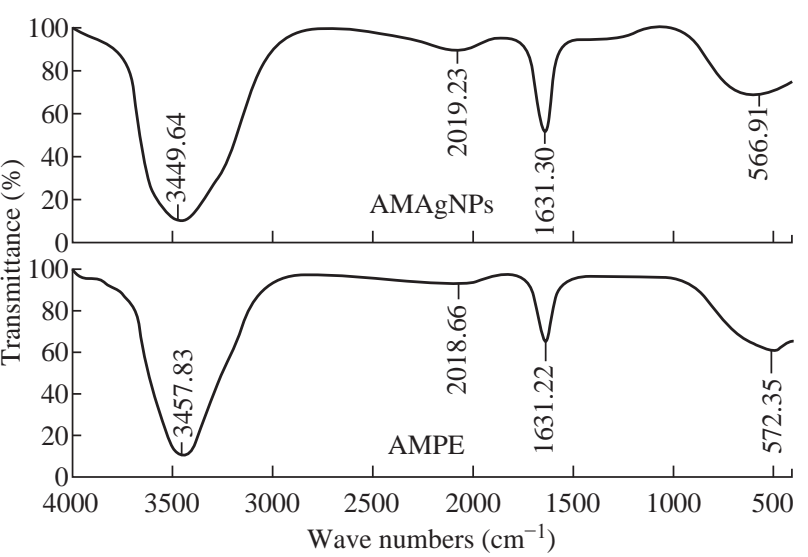

(d) FTIR of AM-AgNPs and A. mexicana plant extract

Fig. 2 Characterization of AM-Ag NPs: (a) SEM microscopic view of AM-Ag NPs; (b) TEM micrograph of AM-Ag NPs, scale bar $=20 \mathrm{~nm}$ and selected area electron diffraction (SAED) pattern at right corner; (c) XRD pattern of AM-Ag NPs synthesized using A. mexicana leaf extract; (d) FTIR spectrum of A. mexicana plant extract and AM-Ag NPs synthesized using aqueous extract of A. mexicana aqueous leaf extract.

cell growth after $48 \mathrm{~h}$ exposure. Comparatively, colon cancer cell line (HCT-15) required more than $50 \mu \mathrm{g} / \mathrm{mL}$ of AM-Ag NPs to inhibit $90 \%$ cell growth. Only the report stating gold nanoparticles synthesized using A. mexicana inhibited cell growth of MCF-7 cells at $100 \mu \mathrm{g} / \mathrm{mL}$ [27] which was found 5 times higher than what we reported for biogenic silver nanoparticles. The silver nanoparticles exerted most recognized noticeable effects on cultured cells with modifications in cellular morphology [14, 28]. When we treated cancer cells with higher concentrations of AM-Ag NPs, evident features of cellular apoptosis with alteration showed in cell morphology with shrunken appearance, cell contraction, extensive membrane bleb and loss of membrane integrity. In this study, the cytotoxic activity of biogenic AM-Ag NPs at concentrations between 0.5 - $50 \mu \mathrm{g} / \mathrm{mL}$ were evaluated in vitro against cervical, breast and colon adenocarcinoma cell lines exposed to Ag NPs up to $48 \mathrm{~h}$. When we exposed cancer cells to 0.5 - $50 \mu \mathrm{g} / \mathrm{mL}$ AM-Ag NPs, we observed that $20 \mu \mathrm{g} / \mathrm{mL}$ of Ag NPs inhibited $95.34 \pm 0.23 \%$ and $97.17 \pm 0.40 \%$ cell growth in HeLa cells after 24 and 48 h exposure respectively (Fig. 3(a)). Similarly, results of MCF-7 cells exposed to $20 \mu \mathrm{g} / \mathrm{mL}$ of Ag NPs showed 96.61 $\pm 0.31 \%$ and $97.46 \pm 0.24 \%$ cell growth inhibition after 24 and 48 h exposure (Fig. 3(c)). However, HCT15 cells treated with increased concentrations of AM$\mathrm{Ag}$ NPs, i.e., $50 \mu \mathrm{g} / \mathrm{mL}$, showed $91.20 \pm 0.22 \%$ and $99.12 \pm 0.35 \%$ cell growth inhibition after 24 and 48 h exposure respectively (Fig. 3(e)). 50\% inhibitory concentration $\left(\mathrm{IC}_{50}\right)$ of $\mathrm{AM}-\mathrm{Ag} \mathrm{NPs}$ required to inhibit cell growth of HeLa cells after 24 and $48 \mathrm{~h}$ exposure were $2.80 \pm 0.73$; $95 \% \mathrm{CI}: 1.34-4.21, \mathrm{p}=0.05$ and $1.94 \pm 0.43$; 95\% CI: $1.56-3.26, p=0.05$ respectively. $\mathrm{IC}_{50}$ of AM-Ag NPs for inhibition of MCF-7 were $3.50 \pm 0.40$; 95\% CI: $2.85-4.46, \mathrm{p}=0.05$ after $24 \mathrm{~h}$ exposure and $1.86 \pm 0.36$; 95\% CI: $1.63-3.07, \mathrm{p}=$ 0.05 after 48 h respectively, whereas $\mathrm{IC}_{50}$ of $\mathrm{AM}-\mathrm{Ag}$ NPs required for inhibition of HCT-15 cell growth were $9.63 \pm 1.10$; 95\% CI: $7.46-11.80, \mathrm{p}=0.05$ after $24 \mathrm{~h}$ exposure, and $4.16 \pm 0.59$; 95\% CI: $3.53-6.87$, $\mathrm{p}=0.05$ after $48 \mathrm{~h}$ exposure. The complete inhibition 


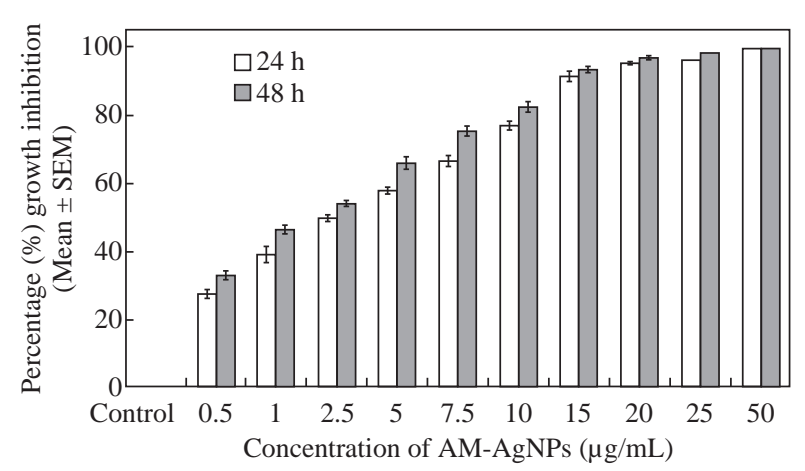

(a) \% growth inhibition of HeLa cells after exposure to AM-AgNPs

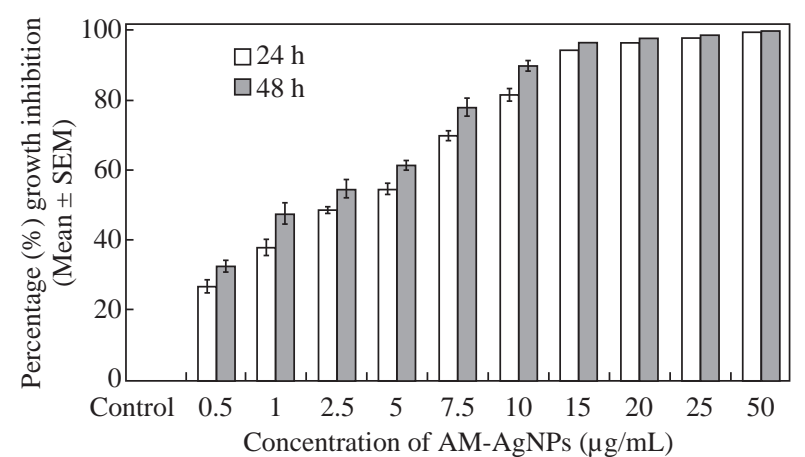

(c) \% growth inhibition of MCF-7 cells after exposure to AM-AgNPs

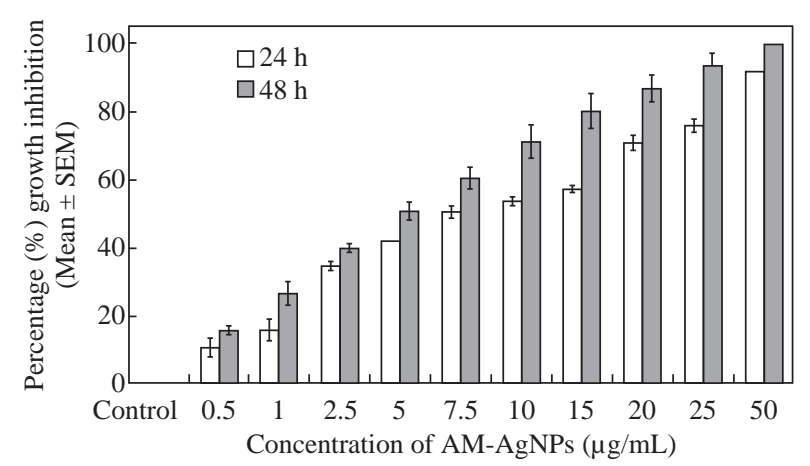

(e) \% growth inhibition of HCT-15 cells after exposure to AM-AgNPs

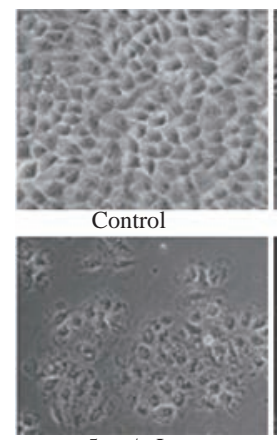

$5 \mu \mathrm{g} / \mathrm{mL}$

(b) Morphology of HeLa cells after $24 \mathrm{~h}$ exposure to AM-AgNPs

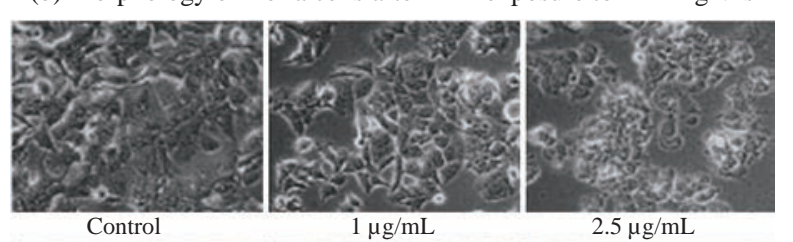

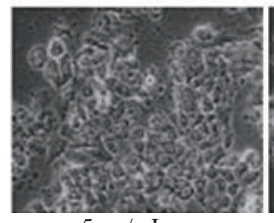

$5 \mu \mathrm{g} / \mathrm{mL}$

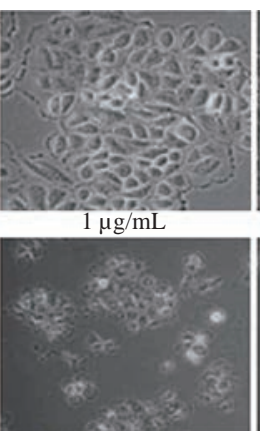

$10 \mu \mathrm{g} / \mathrm{mL}$
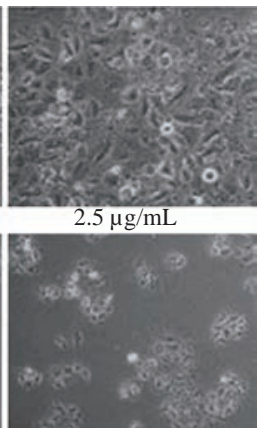

$20 \mu \mathrm{g} / \mathrm{mL}$ (d) Morphology of MCF-7 cells after $24 \mathrm{~h}$ exposure to AM-AgNPs

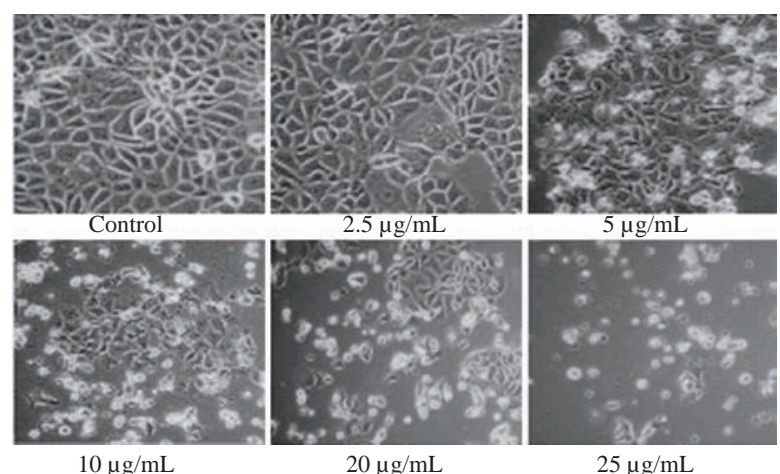

(f) Morphology of HCT-15 cells after $24 \mathrm{~h}$ exposure to AM-AgNPs

Fig. 3 Representative histogram showing in vitro cytotoxicity of biogenic AM-Ag NPs on (a) HeLa cells, (c) MCF-7 cells, (e) HCT15 cells after 24 and 48 h exposure to $0.5,1,2.5,5,7.5,10,15,20,25$ and $50 \mu \mathrm{g} / \mathrm{mL}$ concentrations of biogenic AM-Ag NPs. The results represent the means of 3 independent experiments, error bars representing the standard error of the mean. Cell morphology of (b) HeLa cells and (d) MCF-7 cells after $24 \mathrm{~h}$ exposure of different concentrations of 2.5, 5, 10, 15, and $20 \mu \mathrm{g} / \mathrm{mL}$, and (f) HCT-15 cells exposed to 2.5, 5, 10, 20 and $25 \mu \mathrm{g} / \mathrm{mL}$ of biogenic AM-Ag NPs for $24 \mathrm{~h}$. All images were taken at $20 \times$ magnification with Carl Zeiss phase contrast microscope.

of cell growth ( 99 \%) of HeLa and MCF-7 cells was observed at $25 \mu \mathrm{g} / \mathrm{mL}$, whereas $50 \mu \mathrm{g} / \mathrm{mL}$ of AM-Ag NPs inhibited HCT-15 cell growth. Cell morphological features of treated cells observed under inverted phase contrast microscope revealed the changes in cell morphology, whereas control cells appeared normal (Fig. 3(b), (d) and (f)). It was clearly observed that cells treated at $10 \mu \mathrm{g} / \mathrm{mL}$ and above concentrations possessed systematic morphological alterations such as cell shrinkage, cytoplasmic condensation and loss of membrane integrity as a signature of cell apoptosis. When we tested the cytotoxic activity of A. mexicana plant extract, we found the $\mathrm{IC}_{50}$ concentration of aqueous extract of A. mexicana required to inhibit cell growth after $24 \mathrm{~h}$ exposure was $58.88 \pm 2.74 \mu \mathrm{g} / \mathrm{mL}$ for HeLa cells, $134.89 \pm 2.36 \mu \mathrm{g} / \mathrm{mL}$ for MCF-7 cells, and $60.25 \pm$ $2.60 \mu \mathrm{g} / \mathrm{mL}$ for HCT-15 cells respectively (Supporting Information 2(a)). Also, the cytotoxicity results of chemically synthesized citrate-Ag NPs showed comparatively lower inhibition of cell growth where $200 \mu \mathrm{g} / \mathrm{mL}$ of citrate-Au NPs killed $82.06 \pm 1.29 \%$ of MCF-7 cells, $87.84 \pm 1.20 \%$ of HeLa cells and $90.26 \pm$ $0.80 \%$ of HCT-15 cells (Supporting Information 2(b)). This study demonstrated the cytotoxicity effect of AM- 
Ag NPs on normal fibroblast cells; the results indicated comparatively lower sensitivity of normal fibroblast cells towards either biogenic AM-Ag NPs or citrateAg NPs. By exposing fibroblast cells to $0.5-50 \mu \mathrm{g} / \mathrm{mL}$ AM-Ag NPs as well as citrate-Ag NPs, we observed that even higher concentration, i.e, $50 \mu \mathrm{g} / \mathrm{mL}$, inhibited less than $23.32 \pm 1.2 \%$ and $12.17 \pm 0.26 \%$ cell growth in fibroblast cells after $48 \mathrm{~h}$ exposure respectively (Supporting Information 3(a) and (b)).

\section{DNA fragmentation}

DNA damage is considered as one of the distinctive features of apoptosis process or cell death. The results of cytotoxicity concurred with previous reports where silver nanoparticles showed inhibition of cell proliferation in cancer cells including human breast [29, 30], lung [31], colon [32] and ovarian cancer cells [33] through induction of cellular apoptosis. Biogenic silver nanoparticles are known to exhibit cellular apoptotic effects in various cancer cells in accordance with cytotoxicity by means of different mechanisms causing macromolecular damage including DNA fragmentation [29, 34]. Previous studies reported DNA fragmentation induced cellular apoptosis in different cancer cells when exposed to silver nanoparticles [32], resembling to which our results proved induction DNA fragmentation in HeLa, MCF-7 and HCT-15 cells in response to exposure of biogenic AM-Ag NPs. The DNA isolated from HeLa and MCF-7 cells exposed to 5 - $20 \mu \mathrm{g} / \mathrm{mL}$ and HCT-15 cells exposed to 10 - $50 \mu \mathrm{g} / \mathrm{mL}$ of AM-Ag NPs showed laddering appearance in fragmented DNA, indicating deposition of Ag NPs inside the cell nucleus and inducing dose dependent DNA damage. The results of evaluation of genotoxicity effects of AM-Ag NPs was determined by DNA fragmentation pattern in cancer cells. When HeLa and MCF-7 cells were treated with 0 - $20 \mu \mathrm{g} /$ mL (Fig. 4(a) and (b)) and HCT-15 cells were treated with 0 - $50 \mu \mathrm{g} / \mathrm{mL}$ of AM-Ag NPs, the apoptotic cells showed characteristic DNA laddering from lower to higher concentrations (Fig. 4(c)). The cells treated with AM-Ag NPs exhibited extensive double strand breaks yielding a ladder appearance in DNA (Lane 4-7, Fig. 4(a)-(c)), while DNA of unexposed control cells exhibited minimum or no DNA breakage. Thus, extensive DNA double strand breaks observed in AM-Ag NPs treated cells evidenced the induction of apoptosis in HeLa, MCF-7 and HCT-15 cells.

\section{Effect AM-AgNPs on apoptotic gene and protein expression analysis}

Inhibition of cell proliferation and induction of apoptosis are thought to be the major biological outputs of p53 mediated pathway in response to various types of physiological stressors. In view of this, when we exposed HeLa, MCF-7 and HCT-15 cells with $\mathrm{IC}_{50}$ concentration of AM-Ag NPs up to $48 \mathrm{~h}$ and evaluated the expression of caspase-3 and p53 genes at mRNA level and protein level, we observed significantly upregulated expression of both caspase-3 and p53 in Ag

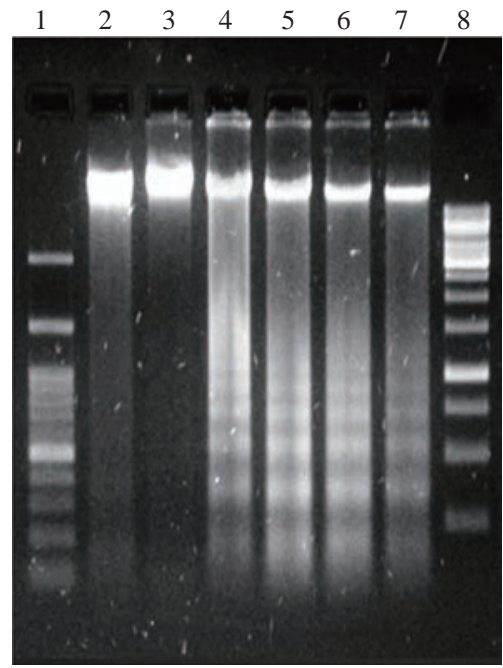

(a) HeLa cells

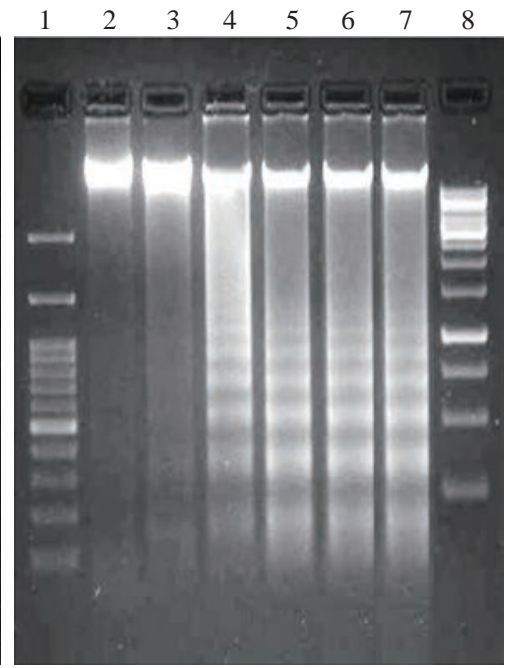

(b) MCF-7 cells

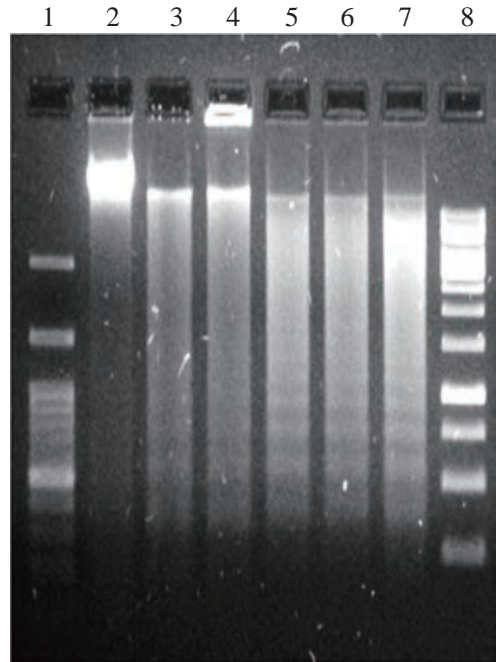

(c) HCT-15 cells

Fig. 4 Genotoxicity of AM-Ag NPs against HeLa, MCF-7 and HCT-15 cells. Representative Agarose gel images showing DNA fragmentation in (a) HeLa, (b) MCF-7 and (c) HCT-15 cells treated with different concentrations of AM-Ag NPs. In each representative gel, lane 1 was 100 bp DNA marker: Lane 2 was DNA from control cells; lane 3-7 were DNA from AM-Ag NPs treated HeLa and MCF-7 cells (2.5, 5, 10, 15 and $20 \mu \mathrm{g} / \mathrm{mL}$ respectively); lane 8 was $1 \mathrm{~Kb}$ DNA marker. HCT-15 cells were exposed to 5, 10, 20, 25 and $50 \mu \mathrm{g} / \mathrm{mL}$ AM-Ag NPs. 
NPs treated cancer cells in time dependent manner as compared to control cells. The enhanced expression of both caspase- 3 and p53 performed a primitive role in activation of apoptosis process. It was evident from our finding that the underlying mechanism of cell death in cancer cells by AM-Ag NPs was intrinsic apoptosis pathway mediated by activation of caspase-3 and p53. These results concurred with the earlier reports stating the regulation of biogenic Ag NPs mediated apoptosis in human breast cancer cells [33] and colon carcinoma cells [32] through involvement of p53 and activation of caspase-3. In this study, the expression apoptotic genes in AM-Ag NPs exposed cancer cells were analyzed using semi-quantitative RT-PCR and western blotting by exposing the cells with $\mathrm{IC}_{50}$ concentration of AM-Ag NPs till $48 \mathrm{~h}$. When we aimed at checking the expression level of caspase-3 and p53 genes, it displayed an evidential enhanced expression of both genes excitingly up-regulated in AM-Ag NPs treated cancer cells as compared to control unexposed cells (Fig. 5(a)). The results represented remarked 2 - 3 fold increased expression of studied caspase-3 and p53 in AM-Ag NPs treated cells as compared to respective controls after 24 and 48 h exposure. Thus, AM-Ag NPs significantly regulated the overexpression of both caspase-3 and p53 genes in all 3 type cells treated with nanoparticles up to $48 \mathrm{~h}(\mathrm{p}<0.001)$ as compared to normal control cells (Fig. 5(b)).

Similarly, apoptotic protein expression analysis was performed to detect apoptotic proteins caspase-3 and p53 using western blot analysis in selected cancer cells exposed to $\mathrm{IC}_{50}$ concentration of AM-Ag NPs for $48 \mathrm{~h}$. Our results depicted that the expression levels of caspase- 3 and p53 proteins were also increased in cancer cells after exposure to AM-Ag NPs. These results signified up-regulation of caspase-3 and p53 proteins to execute the process of apoptosis in AMAg NPs exposed cancer cells as compared to untreated control cells (Fig. 6(a)). The expression of caspase-3 and p53 was observed significantly higher $(\mathrm{p}<0.001)$ in HeLa, MCF-7 and HCT-15 cells when exposed to AM-Ag NPs till $48 \mathrm{~h}$ as compared to untreated

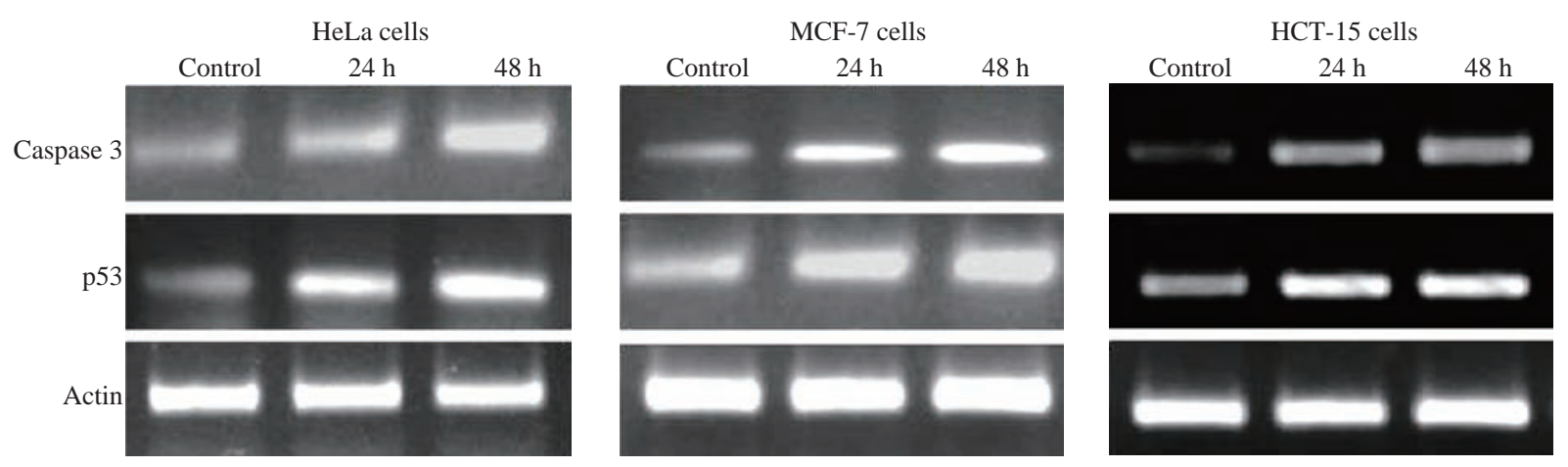

(a) Relative expression levels of caspase 3 \& p53 mRNA in HeLa, MCF-7 and HCT-15 cells
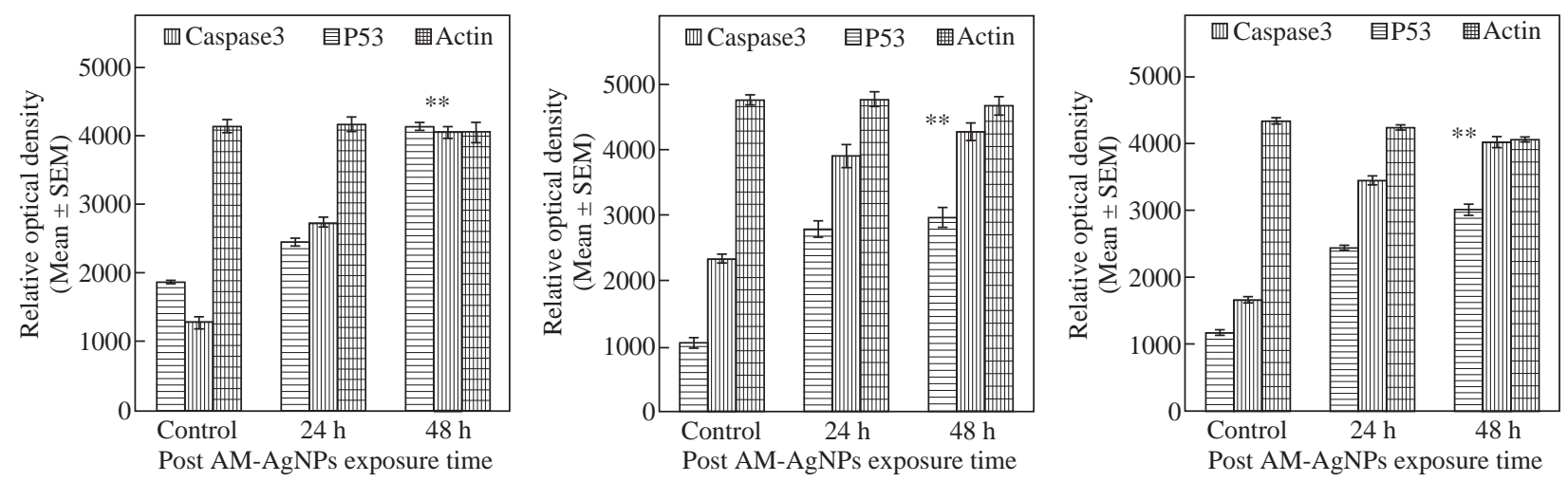

(b) Densitometric analysis of caspase 3 \& p53 mRNA expression levels in HeLa, MCF-7 and HCT-15 cells

Fig. 5 (a) Representative RT-PCR products of caspase-3, p53 and actin genes from HeLa, MCF-7 and HCT-15 cells exposed to IC 50 concentration of AM-Ag NPs with different time points of exposure. Lane 1 was mRNA level of caspase-3 and p53 from control cells; lane 2 and 3 were mRNA levels of AM-Ag NPs exposed cell samples after 24 and 48 h of exposure. (b) Histogram showing relative levels of caspase- 3 and p53 cDNA of HeLa, MCF-7 and HCT-15 cells quantified by densitometry analysis, error bars indicating the standard error of the mean (SEM) for 3 independent experiments $(n=3)$. Significant differences $(* *)$ in mRNA expression between control and AM-Ag NPs exposed samples were assessed by Student's t-test $(\mathrm{p}<0.001)$, results found to be increased significantly in samples obtained from 24 and $48 \mathrm{~h}$ post exposure periods as compared to control. 


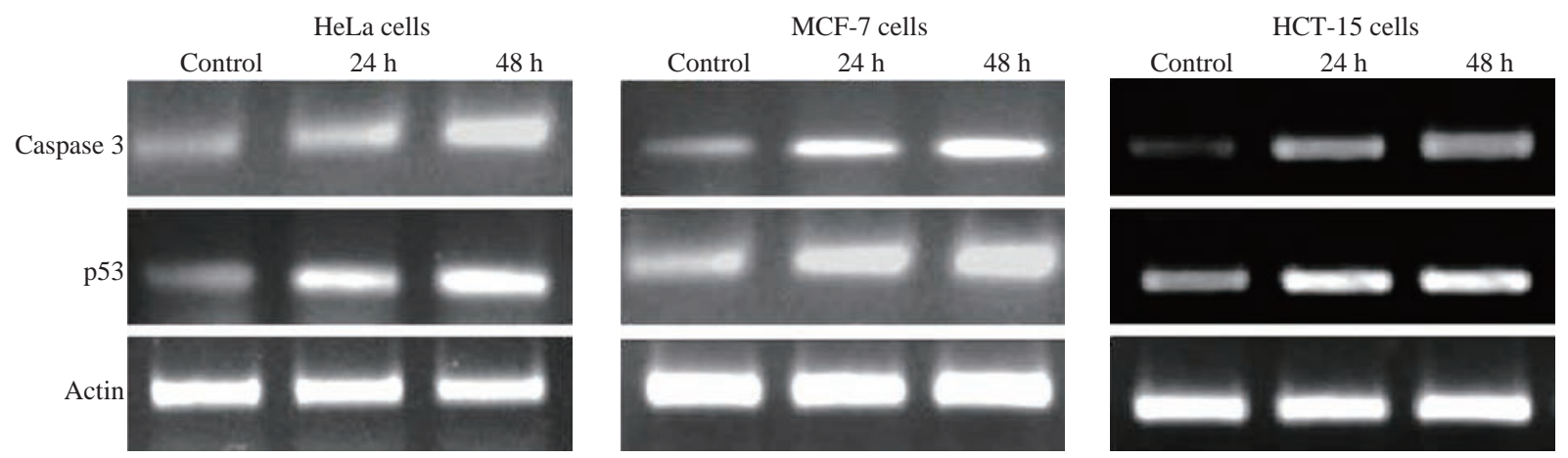

(a) Relative expression levels of caspase 3 \& p53 mRNA in HeLa, MCF-7 and HCT-15 cells
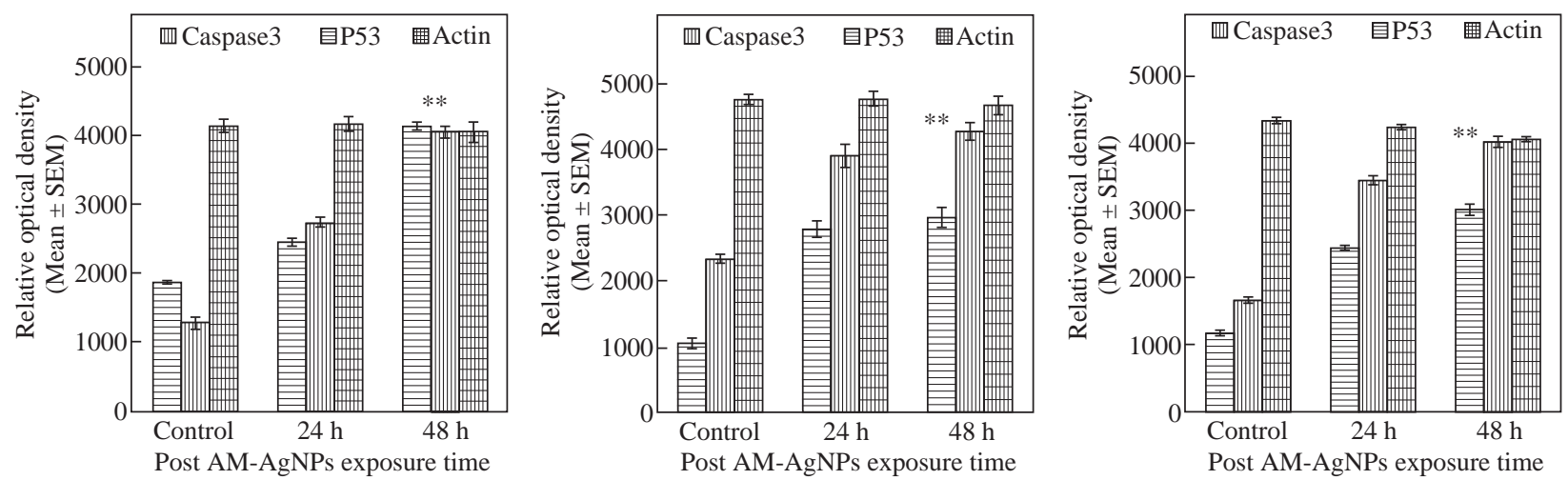

(b) Densitometric analysis of caspase 3 \& p53 mRNA expression levels in HeLa, MCF-7 and HCT-15 cells

Fig. 6 (a) Representative western blot showing expression of caspase-3 and p53 protein form HeLa, MCF-7 and HCT-15 cells exposed to $\mathrm{IC}_{50}$ concentration of AM-Ag NPs with different time points $(\mathrm{n}=3)$. Lane 1 was levels of expression of caspase-3 and p53 from control cells; lane 2 and 3 were expressions of proteins from AM-Ag NPs exposed cells at 24 and 48 h exposure time. Actin was used as internal loading control to compare the expression levels. (b) Histogram showing relative levels of caspase-3 and p53 proteins resolved in western blot were quantitated by densitometric analysis. Error bars indicated the standard error of the mean (SEM) for 3 independent experiments $(n=3)$. Significant differences $(* *)$ were assessed by Student's $t$ test $(\mathrm{p}<0.001)$, results found to be increased significantly in samples obtained from 24 and $48 \mathrm{~h}$ post exposure periods as compared to control.

control cells (Fig. 6(b)). When compared with control cells, 3 fold increased expression of caspase- 3 and p53 occurred in AM-Ag NPs treated cells after $48 \mathrm{~h}$ exposure. We used actin as an internal loading control in both mRNA and protein expression studies and it did not change expression level when compared with other studied elements. Hence, our findings perceptibly indicated the underlying means and mode of inhibition of cell proliferation in cancer cells by AM-Ag NPs was a direct result of activation of intrinsic apoptosis pathway mediated via caspase-3 and p53 dependent manner.

\section{Conclusions}

Around 95\% inhibition of cell proliferation in HeLa and MCF-7 cells was recorded with $25 \mu \mathrm{g} / \mathrm{mL}$ concentration of AM-Ag NPs, whereas $50 \mu \mathrm{g} / \mathrm{mL}$ of AM-Ag NPs was required to kill 95\% of HCT-15 cells. The findings from the current research evidenced involvement of molecular events such as activation of caspase-3 and p53 which were intermediates of apoptotic cell death induced by biogenic AM-Ag NPs. Hence, our study provided plausible evidence supporting that AM-Ag NPs exhibited strong antiproliferative and apoptotic potential against selected cancer cells, suggesting that biogenic AM-Ag NPs could act as a new substitute and help in therapeutics of cervix, breast and colon cancers.

\section{Acknowledgements}

The authors gratefully acknowledge all the facilities and financial support provided by the Krishna Institute of Medical Sciences "Deemed to be University” Karad, India for experimental work. Authors are thankful to Mr. Santosh Jadhav for technical support.

\section{Conflict of Interests}

The authors declare that no competing interest exists. 


\section{References}

[1] A. Maqusood, M. Alsalhi, and M. Siddiqui, Silver nanoparticle applications and human health. Clinica Chimica Acta, 2010, 411(23): 1841-1848.

[2] A. Husen, K. Siddiqi, Phytosynthesis of nanoparticles: concept, controversy and application. Nanoscale Research Letters, 2014, 9(1): 229.

[3] S. Hazarika, K. Gupta, P. Bhardwaj, et al., One-pot facile green synthesis of biocidal silver nanoparticles. Materials Research Express, 2016, 3(7): 075401.

[4] A. Husen, Gold nanoparticles from plant system: synthesis, characterization and their application. Nanoscience and plant-soil systems. Cham: Springer International Publication, 2017: 455-479.

[5] M. Beg, A. Maji, A. Mandal, et al., Green synthesis of silver nanoparticles using Pongamia pinnata seed: characterization, antibacterial property, and spectroscopic investigation of interaction with human serum albumin. Journal of Molecular Recognition, 2017, 30(1): e2565.

[6] S. Lokina, A. Stephen, V. Kaviyarasan, et al., Cytotoxicity and antimicrobial activities of green synthesized silver nanoparticles.European Journal of Medical Chemistry, 2014, 9(76): 256-263.

[7] L. Wei, J. Lu, H. Xu, et al., Silver nanoparticles: synthesis, properties, and therapeutic applications. Drug Discovery Today, 2015, 20: 595-601.

[8] H. Lara, E. Garza-Trevino, L. Ixtepan-Turrent, et al., Silver nanoparticles are broad-spectrum bactericidal and virucidal compounds. Journal of Nanobiotechnology, 2011, 9: 30.

[9] S. Raman, P. Kandula, A. Jacob, et al., Cytotoxic effect of green synthesized silver nanoparticles using Melia azedarach against in vitro HeLa cell lines and lymphoma mice model. Process Biochemistry, 2012, 47(2): 273-279.

[10] V. Kathiravan, S. Ravi, S. Ashokkumar, Synthesis of silver nanoparticles from Melia dubia leaf extract and their in vitro anticancer activity. Spectrochimica Acta Part A: Molecular and Biomolecular Spectroscopy. 2014, 130 : 116-121.

[11] M. Kumarswamy, K. Sudipta, K. Jayanta, et al., The green synthesis, characterization, and evaluation of the biological activities of silver nanoparticles synthesized from Leptadenia reticulata leaf extract. Applied Nanoscience, 2015, 5: 73-81.

[12] K. Hembram, R. Kumar, L. Kandha, et al., Therapeutic prospective of plant-induced silver nanoparticles: application as antimicrobial and anticancer agent. Artificial Cells, Nanomedicine and Biotechnology, 2018, 46(3): S38-S51.

[13] M. Ebrahimzadeh, A. Tafazoli, J. Akhtari, et al., Engineered silver nanoparticles, a new nanoweapon against Ccancer. Anticancer Agents in Medicinal Chemistry, 2018, 18(14): 1962-1969.

[14] P. Asha Rani, G. Low Kah Mun, M. Hande, et al., Cytotoxicity and genotoxicity of silver nanoparticles in human cells. ACS Nano, 2009, 3(2): 279-290.

[15] S. Soenen, P. Rivera-Gil, J. Montenegro, et al., Cellular toxicity of inorganic nanoparticles: common aspects and guidelines for improved nanotoxicity evaluation. Nano Today, 2011, 6: 446-465.

[16] S. Kim, D. Ryu, Silver nanoparticle-induced oxidative stress, genotoxicity and apoptosis in cultured cells and animal tissues. Journal of Applied Toxicology, 2013, 33(2): 78-89.

[17] T. Premkumar, Y. Lee, K. Geckeler. Macrocycles as a tool: A facile and one pot synthesis of silver nanoparticles using cucurbituril designed for cancer therapeutics.
Chemistry-A European Journal, 2010, 16: 11563-11566.

[18] B. Zhu, Y. Li, L. Zhengfang, et al., Silver Nanoparticles Induce HePG-2 Cells Apoptosis Through ROS-Mediated Signaling Pathways. Nanoscale Research Letters, 2016, 11: 198.

[19] M. Bethu, V. Netala, L. Domdi, et al., Potential anticancer activity of biogenic silver nanoparticles using leaf extract of Rhynchosia suaveolens: an insight into the mechanism. Artificial Cells, Nanomedicine and Biotechnology, 2018, 46: 104-114.

[20] K. Nagarajan, L. Deyu, K. Soundarapandian, Induction of intrinsic apoptotic signaling pathway in A549 lung cancer cells using silver nanoparticles from Gossypium hirsutum and evaluation of in vivo toxicity. Biotechnology Reports, 2019, 23: e00339.

[21] B. Borrell, Drug developers take a second look at herbal medicines. Scientific American, 2014, 310(6): 64-69.

[22] D. Tewari, A. Mocan, E. Parvanov, A. Sah et al., Ethnopharmacological Approaches for therapy of Jaundice: Part I. Frontiers in Pharmacology, 2017, 8: 518.

[23] A. Singh, D. Jain, M. Upadhyay, et al., Synthesis of silver nanoparticles using Argemone mexicana leaf extract and evaluation of their antimicrobial activities. Digest Journal of Nanomaterials and Biostructures, 2010, 5(2): 483-489.

[24] N. Chandrashekhar, S. Vinay, Yellow colored blooms of Argemone mexicana and Turnera ulmifolia mediated synthesis of silver nanoparticles and study of their antibacterial and antioxidant activity. Applied Nanoscience, 2017, 7: 851-861.

[25] P. Nagajyothi, T. Sreekanth, J. Lee, et al., Mycosynthesis: antibacterial, antioxidant and antiproliferative activities of silver nanoparticles synthesized from Inonotus obliquus (Chaga mushroom) extract. Journal of Photochemistry and Photobiology:B Biology, 2014, 130: 299-304.

[26] P. RathiSre, M. Reka, R. Poovazhagi, et al., Antibacterial and cytotoxic effect of biologically synthesized silver nanoparticles using aqueous root extract of Erythrina indica lam. Spectrochimica Acta Part A: Molecular and Biomolecular Spectroscopy, 2015, 135: 1137-1144.

[27] S. Varun, S. Sellappa, Enhanced apoptosis in MCF-7 human breast cancer cells by biogenic gold nanoparticles synthesized drom Argemone mexicana leaf extract. International Journal of Pharmacy \& Pharmaceutical Sciences, 2014, 6(8): 528-531.

[28] P. Gopinath, S. Gogoi, A. Chattopadhyay, et al., Implications of silver nanoparticle induced cell apoptosis for in vitro gene therapy. Nanotechnology, 2008, 19: 075104.

[29] S. Gurunathan, J. Han, V. Eppakayala, et al., Cytotoxicity of biologically synthesized silver nanoparticles in MDAMB-231 human breast cancer cells. Biomed Research International, 2013, 2013: 535796.

[30] M. Azizi, H. Ghourchian, F. Yazdian, et al., Anticancerous effect of albumin coated silver nanoparticles on MDA-MB 231 human breast cancer cell line. Scientific Reports, 2017, 7: 5178.

[31] J. Han, S. Gurunathan, J. Jeong, et al., Oxidative stress mediated cytotoxicity of biologically synthesized silver nanoparticles in human lung epithelial adenocarcinoma cell line. Nanoscale Research Letters, 2014, 9: 459.

[32] S. Gurunathan, M. Qasim, C. Park, et al., Cytotoxic Potential and Molecular Pathway Analysis of Silver Nanoparticles in Human Colon Cancer Cells HCT116. International Journal of Molecular Sciences, 2018, 19: 2269.

[33] S. Gurunathan, J. Han, J. Park, et al., Reduced graphene oxide-silver nanoparticle nanocomposite: A potential anticancer nanotherapy. International Journal of 
Nanomedicine, 2015, 10: 6257-6276.

[34] X. Zhang, W. Shen, S. Gurunathan, Silver NanoparticleMediated Cellular Responses in Various Cell Lines: An in Vitro Model. International Journal of Molecular Sciences, 2016, 17: 1603-1637.

Copyright $@$ Kailas Dhondibhau Datkhile, Satish Ramchandra
Patil, Pratik Prakash Durgawale, Madhavi Narayan Patil, Nilam Jagannath Jagdale, Vinit Nitin Deshmukh, and Ashwini Laxman More. This is an open-access article distributed under the terms of the Creative Commons Attribution License, which permits unrestricted use, distribution, and reproduction in any medium, provided the original author and source are credited. 